\title{
Managerial Compensation and Corporate Bond Yield with Active Shareholders
}

\author{
Vittoria Cerasi ${ }^{1} \&$ Sonja Daltung ${ }^{2}$ \\ ${ }^{1}$ Department of Economics, Management and Statistics, Bicocca University, Milano, Italy \\ ${ }^{2}$ Swedish Agency for Growth Policy Analysis, Studentplan 3, S-831 40 Östersund, Sweden \\ Correspondence: Vittoria Cerasi, Department of Economics, Management and Statistics, Bicocca University, \\ Piazza dell'Ateneo Nuovo 1, 20126 Milano, Italy. E-mail: vittoria.cerasi@unimib.it
}

Received: March 29, 2017

Accepted: April 18, 2017

Online Published: May 15, 2017

doi:10.5539/ijef.v9n6p111

URL: https://doi.org/10.5539/ijef.v9n6p111

\begin{abstract}
In this paper we show how a greater pay-for-performance in managerial compensation may reduce the cost of corporate debt. The model points to the relation between the bonus and the monitoring effort by shareholders as key to reduce the cost of debt and hence increase the value of the company. Incentivizing the manager with a bonus related to the company's performance, provided that the information is disclosed to investors, not only reduces the moral hazard between managers and shareholders, but more importantly between shareholders and bond-holders. The model predicts i) a lower corporate bond yield when there is disclosure of managerial pay-performance to financial markets, and ii) an increasing degree of managerial pay-for-performance with company's leverage.
\end{abstract}

Keywords: managerial compensation; financial structure; shareholders' monitoring

\section{Introduction}

In modern companies managers and shareholders together contribute to enhance firm's value; they are, however, in competition when sharing the firm's revenues, not only internally, but also with outside investors (as pointed out by Jensen \& Meckling, 1976).

Designing the optimal managerial compensation has to account for this double-edged competition. While a higher compensation improves managerial effort, it also reduces the amount of resources available to reward shareholders and bondholders for their investment in the firm. The impact of a managerial compensation scheme on company value crucially depends on the effect on all parties' incentives.

The interplay between managerial compensation and the financial structure of a firm is not new in literature (see Murphy, 1999, for a review). We depart from such literature by explicitly introducing shareholders' monitoring. There are at least two reasons for why shareholders' monitoring is important. First, shareholders' monitoring on managerial effort improves company value: Core et al. (1999) find evidence that governance structures with greater control on managers improve company performance, while Huson et al. (2001) show that monitoring by shareholders increases the rate of replacement of managers in response to a poor company performance. Second, although managerial effort is essential, the empirical evidence on managerial compensation is controversial: for example Jensen and Murphy (1990) document that CEO pay-performance sensitivity is only $3.25 \$$ per $1000 \$$ change in shareholder value. This evidence questions the effectiveness of monetary incentives alone, without shareholders' monitoring, to enhance managerial effort.

The paper analyzes the governance channels in a firm run by a manager and owned by concentrated shareholders (the entrepreneur). In the model there are two tools to influence the governance of the firm. The internal channel is the standard one where shareholders may induce more effort by the manager with a bonus related to performance (pay-for-performance). The novelty in the analysis is due to the external governance channel. External funding in the form of debt adds an interesting twist to the standard channel. Assuming that monitoring by shareholders is essential for the manager to exert effort, we show that pay-for-performance may either reduce or increase the effectiveness of the external governance channel. The magnitude of this effect depends on the amount of firm's leverage. If the firm has no debt, the effect of pay-for-performance on external governance is unambiguously negative: increasing pay-for-performance leaves a smaller share of profits to the shareholders 
and reduces their incentives to monitor. However, if a firm has leverage, additional effects are introduced due to the agency problem between the entrepreneur and bond-holders.

More specifically in the model we assume that the manager is subject to moral hazard: monetary incentives and shareholders' monitoring motivate his effort. Given that shareholders' monitoring is unobservable to outsiders, there is an additional moral hazard between shareholders and bond-holders. In a leveraged firm, this moral hazard curtails insiders effort. Our findings show that shareholders might find it optimal to pay a bonus not only to increase their manager's effort but to show bond-holders a greater commitment towards monitoring. When managers exert a greater effort, the likelihood of company default decreases; given that shareholders are residual claimants of any benefit from monitoring when the firm is solvent, their incentive to monitor increases. Even a small managerial bonus helps to restore correct incentives for insiders, creating a virtuous circle, by reducing the cost of external debt and enhancing total company value. This benefit is greater in leveraged firms. The crucial assumption for the result is that investors observe the managerial compensation. The result offers a rationale for why disclosure on managerial compensation is beneficial when firms demand external finance.

The implications of the model find empirical support in Duru et al. (2005) concerning the relation between managerial bonuses, corporate bond yields and leverage.

The research outlined in this paper relates to the literature on managerial compensation and financial structure of the firm (John \& John, 1993; Berkovitz et al., 2000; Dessi, 2001; Calcagno \& Renneboog, 2007). There the focus is on asset substitution efforts of insiders, while we focus on the monitoring effort of the owner. This has different implications for optimal managerial compensation. In the literature investigating asset substitution, shareholders and managers' interests are aligned through an increase in the pay-performance sensitivity of managerial compensation, by means of bonuses or stock-holdings. In a leveraged firm, greater pay-performance sensitivity of managerial compensation increases the cost of debt since bondholders anticipate the increased asset substitution attitude of managers; thus pay-performance sensitivity must decrease with the level of debt. Here, instead, it is shown that a greater sensitivity to company revenues improves not only managerial effort, but -most importantly -shareholders' monitoring, reinforcing insiders' incentives to exert extra effort. This has a positive consequence on the cost of debt. While a managerial bonus alone introduces a problem of competition for scarce resources between company insiders and outsiders, shareholders' monitoring helps to mitigate this competition.

The idea of efficiency wages (see Shapiro \& Stiglitz, 1984, and subsequent papers) is here applied to managerial compensation schemes: managers' moral hazard is curbed through monetary incentives, but in addition shareholders monitor and punish their managers when any shirking is detected. This paper underlines the importance of insiders' monitoring as in the literature on shareholders' monitoring (see for instance Huddart, 1993; Aghion \& Tirole, 1997; and Burkart et al., 1997). Although we share the opinion expressed in the literature that the efforts of shareholders and managers are both essential for the project, we differ in that we believe that the efforts are complementary, and we thus focus on the case of under-provision of monitoring.

Finally we share some insights with the literature on financial structure as incentive mechanism (Dewatripont and Tirole, 1994), and on debt as an optimal incentive mechanism when insiders exert unobservable effort (Innes, 1990; Cerasi \& Daltung, 2000, Guembel \& White, 2002). In this paper, we add the interaction between managerial effort and the efforts of the owners.

The remainder of the paper is organized as follows: Section 2 describes the basic model, Section 3 analyzes the equilibrium efforts and debt rate, and Section 4 solves for the optimal managerial compensation. Section 5 analyzes the effect of changes in leverage on the optimal managerial compensation. Section 6 extends the basic model from single project to greater number of projects. The empirical predictions of the model are contained in Section 7 and concluding remarks in Section 8.

\section{The Setup}

Consider a three-date economy $(T=0,1,2)$ with three types of agents: entrepreneurs, investors and managers. Entrepreneurs, without capital, start up risky projects. Investors have capital to invest. Managers can enhance the success of the risky project. Each entrepreneur hires a manager to run a project and raises funds from investors.

Each risky project in the economy requires 1 unit of capital at date 0 and returns $R>1$ at date 2 with probability $p$. This probability depends on the combined efforts of the manager and the entrepreneur.

The manager exerts an effort $\mathrm{e} \in[0,1]$ at a private cost $\frac{E}{2} e^{2}$ with $\mathrm{E} \geq 0$. The entrepreneur has access to a monitoring technology: by monitoring with intensity $\mathrm{m} \in[0,1]$, he detects with probability $\mathrm{m}$ misbehavior by his 
manager. The monitoring effort costs $\frac{M}{2} m^{2}$ with $\mathrm{M}>0$. Finally $\mathrm{E} \geq \mathrm{M}>0$ since running a project requires more time than monitoring it (Note 1). The two costly efforts, monitoring and managerial effort, cannot be observed outside the firm: given that the entrepreneur cannot observe the behavior of the manager without costs and investors cannot observe neither of the two insiders' efforts, a double moral hazard is present in the model.

The combined impact of the effort of the manager and of the monitoring of the entrepreneur is captured by the probability of success of the project $\mathrm{p} \in\left[\mathrm{p}_{\mathrm{L}}, \mathrm{p}_{\mathrm{H}}\right]$ with $\Delta \equiv \mathrm{p}_{\mathrm{H}}-\mathrm{p}_{\mathrm{L}}>0$. However the specific form of the probability derives from the outcome of the strategic interaction of the manager and of the entrepreneur, as it will become clear in the next sub-section.

We assume that the minimum expected return of the risky project, when zero effort is exerted, is lower than the gross return from an alternative value preserving investment returning 1 with certainty, i.e.

$$
\mathrm{p}_{\mathrm{L}} \mathrm{R}<1
$$

while the maximum expected return, net of the cost of effort, is greater than the alternative return.

$$
\mathrm{P}_{\mathrm{H}} \mathrm{R}-\frac{E}{2}>1
$$

The timing of the model is as follows. At the beginning of date 0 , the entrepreneur sets the managerial compensation. Then the entrepreneur raises funds from perfectly competitive capital markets and at date 1 entrepreneur and manager choose, respectively, monitoring effort $m$ and managerial effort e. Effort choices are not observable, while returns from projects are observable to outsiders. At date 2 project returns are realized and claims are settled. Figure 1 summarizes the timing of the model.

\begin{tabular}{cccc}
$\mathrm{T}=0$ & & $\mathrm{~T}=1$ & $\mathrm{~T}=2$ \\
\hline $\mid$ & $\mid$ & $\mid$ & $\mid$ \\
entrepreneur & contract with & entrepreneurs and & projects \\
sets & investors & managers & mature; \\
managerial & is signed & choose & claims \\
compensation & & efforts & are settled
\end{tabular}

Figure 1. Timing of the game

With this timing we assume that investors observe the managerial compensation. The model is solved backwards: equilibrium effort, monitoring and return to investors are computed for given managerial compensation. Then, entrepreneur's optimal choice of managerial compensation is resolved.

\subsection{Managerial Compensation}

The manager, who responds to monetary incentives, is offered a managerial compensation, sum of a fixed salary and a bonus. The fixed salary is set equal to the zero outside option of the manager. The managerial bonus $b \in[0$, $\mathrm{R}]$ is by contract dependent on the observable return of the project and it is paid whenever the project succeeds. However the entrepreneur retains the option to fire the manager, when, as a result of monitoring, he detects misbehavior by the manager (Note 2). When the old manager is fired and replaced by a new manager from outside, the project's probability of success switches to $\varphi \in\left[\mathrm{p}_{\mathrm{L}}, \mathrm{p}_{\mathrm{H}}\right]$, depending on the average ability of outside managers. The entrepreneur and the manager choose their efforts non-cooperatively and simultaneously. In Figure 2 we draw the tree that describes the strategic interaction of the entrepreneur and of the manager as well as their gross revenues, for given effort choices.

From Figure 2 we derive the specific form of the probability of success of the project

$$
p=p_{L}+e \Delta+m(1-e)\left(\varphi-p_{L}\right)
$$

The probability of success is $\mathrm{p}_{\mathrm{H}}$ when the manager exerts effort, while $\mathrm{p}_{\mathrm{L}}$ when the manager shirks without being detected; otherwise, the probability is $\varphi$ if the manager is fired and replaced by a new manager from outside. Expression (3) shows the benefit of monitoring: monitoring improves the success probability of the project by detecting shirking and replacing the old manager with a more efficient one. This benefit is larger the greater the probability of shirking and the higher the quality of outside managers, $\varphi>p_{L}$.

For given managerial compensation, the expected utility of the manager is: 


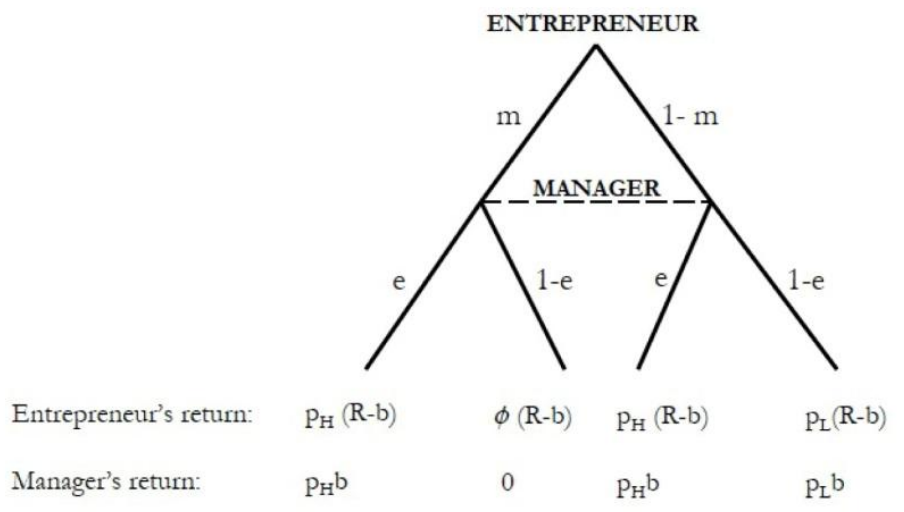

Figure 2. Game tree

Note. The tree represents the strategic interaction in the choices of monitoring $\mathrm{m}$ by the entrepreneur and effort e by the manager. Entrepreneur and manager choose efforts simultaneously and non-cooperatively. When the entrepreneur monitors with intensity $\mathrm{m}$ the manager has the choice between exerting effort or shirking to save the private cost of effort. When the manager behaves he earns the bonus with probability $\mathrm{p}_{\mathrm{H}}$ otherwise, when caught shirking, he is fired. A new manager assures the probability of success $\varphi \in\left(\mathrm{p}_{\mathrm{L}}, \mathrm{p}_{\mathrm{H}}\right)$ and earns the bonus when the project succeeds. When the entrepreneur does not monitor, the manager earns the bonus with probability $\mathrm{p}_{\mathrm{H}}$ when behaving, otherwise with the lowest probability $\mathrm{p}_{\mathrm{L}}$.

where $\mathrm{q}=e \mathrm{p}_{\mathrm{H}}+(1-\mathrm{e})(1-\mathrm{m}) \mathrm{p}_{\mathrm{L}}$ is the probability that the manager is rewarded the bonus. When the manager exerts effort $\mathrm{e}$, he earns the managerial bonus with probability $\mathrm{p}_{\mathrm{H}}$; if he shirks his duties and the entrepreneur does not detect him, he earns the managerial bonus with probability $p_{L}$; finally he is not paid the bonus when fired with probability $m(1-e)$. Notice that the probability of pocketing the bonus for the insider manager is lower compared to the success probability of the project, that is $q-p=-m(1-e) \varphi<0$. The reason is, the project might still succeed due to the new manager's effort, but the old manager is not rewarded the bonus because he is fired. In this case the bonus is still paid conditional on success but to the new manager (Note 3 ).

\subsection{Financing of the Firm}

To derive the expected profit of the entrepreneur we need to consider the financing of the firm. To start the project, the entrepreneur with $\omega$ units of inside equity issues $D=1-\omega$ units of debt on perfectly competitive financial markets. For each unit, the debt claim promises to pay a face value $r$ on date 2 whenever the project is successful, due to limited liability by the entrepreneur. The expected profit of the entrepreneur (the owner or the main shareholder of the firm) can be expressed as:

$$
\pi=p(R-b-r D)-\omega-\frac{M}{2} m^{2}
$$

where the first term represents the expected total return from the project net of managerial bonus and repayment to debt-holders, the second term is the opportunity cost of entrepreneur's capital and the third term is the monitoring cost. Expression (5) shows the competition for project revenues between managers and investors; a larger managerial bonus shrinks the amount of revenues to repay investors for given probability of success of the project. However, the probability of success of the project is not constant but it changes with monitoring and managerial effort.

In addition, expression (5) shows the risk of default of debt. Since the entrepreneur is subject to limited liability but invests in a risky project, debt-holders earn the promised face value $r$ only with probability $p$ : greater monitoring and managerial effort lead to greater probability of honoring the debt and smaller probability of default.

Anticipating the probability of default, investors require their claim to return at least the alternative return 1 , that is:

$$
p r=1
$$

When investors anticipate a greater probability of success, they demand a smaller face value of debt given condition (6), and this releases resources for insiders, either managers or shareholders. 


\section{Equilibrium Efforts and Debt Rate}

We now turn to the equilibrium effort choices, monitoring and managerial effort, and to the equilibrium debt rate, for a given managerial bonus $b$. The entrepreneur and the manager choose simultaneously and non-cooperatively their efforts; then investors, anticipating the equilibrium efforts, set the debt rate accordingly. We characterize the equilibrium of the game in the following Proposition:

Proposition 1. The equilibrium in which the manager exerts effort $\widehat{e}$, the entrepreneur exerts monitoring effort $\widehat{m}$ and pays to investors the debt rate $\widehat{r}$, is characterized by the solution to the following equations:

$$
\begin{gathered}
{\left[\Delta+\widehat{m} p_{L}\right] b-E \widehat{e}=0,} \\
\Delta(\phi)[1-\widehat{e}][R-b-\widehat{r} D]-M \widehat{m}=0, \\
\widehat{p} \widehat{r}=1 .
\end{gathered}
$$

where $\Delta(\varphi) \equiv \varphi-p_{L}$ is an increasing function in $\varphi \in\left[\mathrm{p}_{\mathrm{L}}, \mathrm{p}_{\mathrm{H}}\right]$ attaining its maximum value at $\Delta \equiv \Delta\left(\mathrm{p}_{\mathrm{H}}\right)$ and where

$$
\widehat{p}=p_{L}+\widehat{e} \Delta+\widehat{m}[1-\widehat{e}] \Delta(\phi)
$$

is the equilibrium probability of success of the risky project.

Proof. See in Appendix A.

Eq.(7) shows that, for a given bonus, the effort of the manager improves with monitoring: greater monitoring increases the probability of being caught shirking and thus fired, inducing a greater managerial effort.

Eq.(8) shows that, for a given bonus and debt rate, the benefit of monitoring depends negatively upon the managerial effort due to a free-riding problem: a greater managerial effort improves the probability of success of the project without costs for the entrepreneur, while monitoring entails a positive private cost. The entrepreneur prefers the manager to exert the effort to save his private cost of monitoring.

Finally, according to eq.(9), in equilibrium investors adjust the debt rate so that the expected return from risky debt equals the alternative return 1. Once we substitute the equilibrium efforts, monitoring and debt rate in eq.(5) the equilibrium expected profit of the entrepreneur is:

$$
\widehat{\pi}(b)=\widehat{p}(b)(R-b)-1-\frac{M}{2} \widehat{m}(b)^{2},
$$

We now turn to the analysis of the optimal managerial compensation.

\section{Optimal Managerial Compensation}

For a given debt rate an increase in the level of the bonus has a positive impact on managerial effort, but a negative impact on monitoring. We can see this from Figure 3 where the best reply functions are drawn from equations (7) and (8).

The Nash equilibrium is defined as the intersection between the two best reply functions. For a given debt rate, as the level of the bonus rises from 0 to $\mathrm{b}>0$, the equilibrium moves from $\mathrm{Q}$ to $\mathrm{N}$, where the effort of the manager is higher, while monitoring is lower: the two efforts are substitutes since the bonus improves managerial effort, reducing the benefit of monitoring.

When we allow for a change in the debt rate, the effect of a greater managerial effort on the monitoring may vary. A greater managerial effort increases the probability of success of the project, reducing the face value of debt anticipated by investors; then the marginal benefit of monitoring rises inducing greater monitoring. The implication in term of Figure 3 is that the vertical intercept of the entrepreneur's best reply function shifts up as a consequence of a lower debt rate. The intersection of the two functions takes place at a higher monitoring level, in point $\mathrm{P}$ instead of $\mathrm{N}$ and the two equilibrium efforts become complements.

This result derives from the effect of a larger bonus on the size of the moral hazard between entrepreneur and investors. For a given debt rate, the marginal benefit of monitoring is partially appropriated by investors, as a greater monitoring reduces the probability of default of the risky debt, investors are paid more often the face value, but this reduces the monitoring effort of the entrepreneur. The severity of this moral hazard depends on the size of the managerial bonus. A greater bonus reduces this dis-incentive to monitor.

This consideration is important when we analyze changes in the level of the managerial bonus. At date 0 the entrepreneur sets the level of the managerial bonus to maximize his expected profit in (11) by anticipating effort choices and debt rate. 


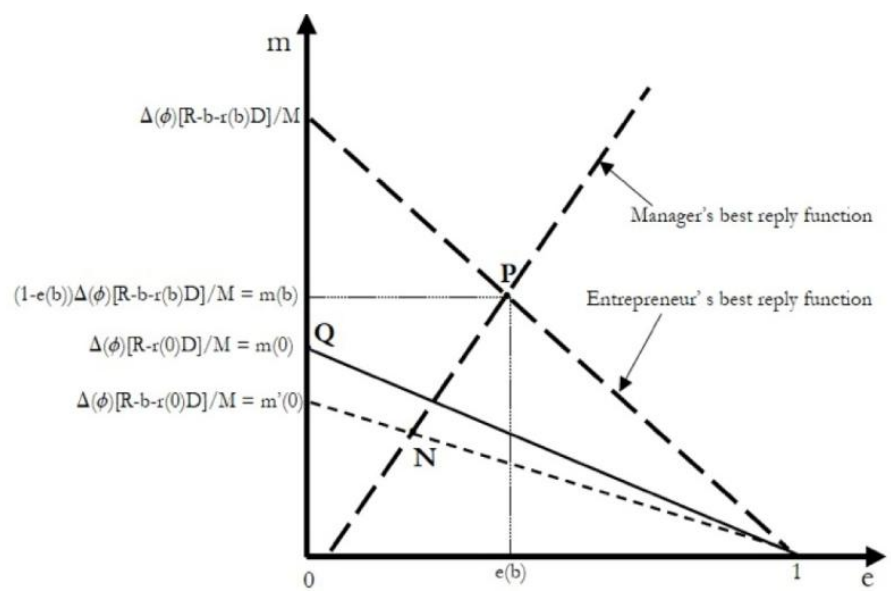

Figure 3. Equilibrium efforts

Note. The diagram represents the best reply functions of the entrepreneur and the manager with and without the bonus $b$. Without the bonus the equilibrium is in $\mathrm{Q}$ with monitoring $\mathrm{m}(0)$ and zero managerial effort. For a positive level of the bonus, $\mathrm{b}>0$, the best reply functions are given by the two dashed lines and the equilibrium is in $\mathrm{P}$. The point $\mathrm{N}$ is not an equilibrium as the interest rate is $\mathrm{r}(0)$ while it has to be adjusted for the success probability at the new equilibrium efforts $\mathrm{e}(\mathrm{b})$ and $\mathrm{m}(\mathrm{b})$ with the bonus, i.e. to $\mathrm{r}(\mathrm{b})<\mathrm{r}(0)$.

The impact of a greater managerial bonus on the monitoring intensity in equilibrium can be separated into two effects, one negative, one positive. The negative effect derives from the direct impact on the project revenue: given the monitoring effort a higher managerial bonus implies a greater share of project return to the manager, improving manager's effort but conversely reducing the incentive of the entrepreneur to monitor. The positive effect derives from the impact on the moral hazard between entrepreneur and investors: a greater bonus increases the effort of the manager reducing the probability of default on the debt, thus strengthening the monitoring incentive of the entrepreneur.

To conclude, a larger managerial bonus may have a positive impact on the probability of success of the project. We can state the following result.

Proposition 2. There exists a threshold value $\bar{m} \in(0,1)$ such that the probability of success with the managerial bonus is higher than without it, $\widehat{p}(b)>\widehat{p}(0)$, if the entrepreneur monitoring effort with the bonus $\widehat{m}(b)$ is greater than $\bar{m}$.

Proof. See in Appendix A.

To conclude, investors, anticipating that with the bonus the manager exerts a higher effort and that a smaller probability of default of the project increases the monitoring effort of the entrepreneur, demand a lower interest rate. This reduces the cost of external finance and improves, in equilibrium, the expected profit. The bonus serves as an optimal commitment to increase the monitoring effort of the entrepreneur.

\section{Leverage}

The model shows the optimality of managerial bonuses as a way for the entrepreneur to commit to a higher level of monitoring level. This result depends on the level of debt over total assets, i.e., the firm's leverage. Proposition 2 shows that the benefit of the managerial bonus may be important enough to achieve greater probability of success. To see when this result occurs, we conduct a comparative statistics exercise.

Proposition 3. The threshold $\bar{m} \in(0,1)$ decreases with the amount of debt $D$.

Proof. See in Appendix A.

As the level of debt increases, the moral hazard problem of the entrepreneur becomes more acute; at the equilibrium the level of monitoring decreases. This reduces the equilibrium profit. An increase in the managerial bonus increases the managerial effort and thus ameliorates the moral hazard of the entrepreneur. This reduces the cost of external finance and increases the equilibrium expected profit.

In Figure 4 we provide an illustration, within a numerical example, of the behavior of the entrepreneur's equilibrium monitoring effort and profit relatively to the managerial bonus for different levels of debt $D=0$ and $D=1$. 
In Figure 4 (right panel) expected profit is drawn for different bonuses and leverage. Expected profit with $\mathrm{D}=0$ is always higher than with $D=1$ since in the first case one of the two moral hazard problems is not present and this allows to reach a more efficient outcome. The result of a positive optimal level of the bonus is conditional on the firm being leveraged, otherwise when $D=0$ it reduces the equilibrium expected profit. Given that debt is risky, debt-holders expect not to be paid the face value $r D$ whenever the project fails: expected shortfalls on debt are $r D(1-p)$. The greater this term the greater the moral hazard of the entrepreneur. In Figure 4 (left panel) expected shortfalls for debt-holders are drawn together with the monitoring intensity of the entrepreneur. Monitoring intensity and expected shortfalls are inversely correlated when $D=1$, implying that the optimality of the bonus depends on its effect on the moral hazard of the entrepreneur. When $D=O$ instead expected shortfalls are zero for any level of the bonus and this effect is absent.
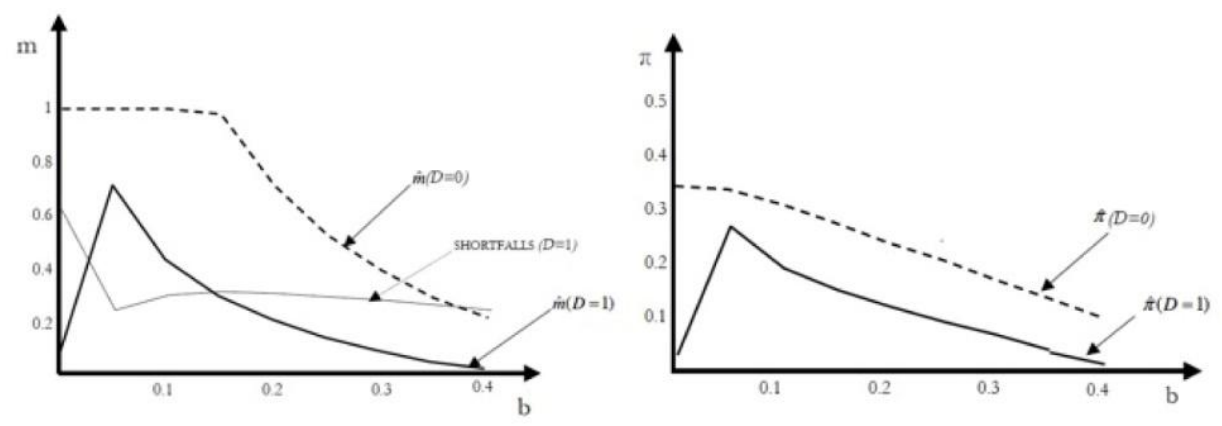

Figure 4. Equilibrium monitoring and profits

Note. The figure is drawn for success probabilities of the project $\mathrm{p}_{\mathrm{H}}=0.9$ and $\mathrm{p}_{\mathrm{L}}=0.6$, outside manager's probability of success $\varphi=0.85$, project return $\mathrm{R}=1.65$, monitoring cost $\mathrm{M}=0.1$ and effort cost $\mathrm{E}=0.18$. The panel on the left represents the entrepreneur's equilibrium monitoring $\mathrm{m}$ for different levels of debt, $\mathrm{D}=0$ and $\mathrm{D}=1$, as the bonus $\mathrm{b}$ rises. On the same diagram the thin dashed line represents the expected losses (shortfalls) on the face value of debt when $\mathrm{D}=1$. The panel on the right represents the firm's equilibrium profit $\pi$ for different levels of debt, $\mathrm{D}=0$ and $\mathrm{D}=1$, as the bonus $\mathrm{b}$ rises.

The optimal managerial bonus is larger in firms with greater leverage. Conversely, the larger the inside equity the smaller the moral hazard of the entrepreneur.

The same can be shown referring to Figure 3 when $D=0$. Starting from $b=0$, as the bonus increases to $b>0$ the equilibrium switches from $\mathrm{Q}$ to $\mathrm{N}$. In equilibrium the level of monitoring decreases while managerial effort improves (only substitution effect). In this case there is neither the benefit from external finance nor a role for the managerial bonus. The beneficial effect of the bonus derives from the impact on the debt rate through an upward shift of the best reply function of the entrepreneur. This proves that leverage is essential for the beneficial effect of the bonus.

\section{Extension: A Larger Number of Projects}

The result on the optimal managerial bonus may depend upon the size of the firm or the degree of diversification of firm's projects. We extend the basic model from a single project to 2 projects to see how the results in the previous section are affected by a change in the number of independent projects.

We consider two cases: case A where the degree of diversification is increased at given size of the firm and case $B$ where an increase in the degree if diversification is associated to a greater size (Note 4).

Case A: To analyze the effect of a greater diversification of projects without changing the size of the firm, we assume that the entrepreneur invests one unit of capital into 2 independent projects each one returning $\frac{R}{2}$ with probability $p, 0$ otherwise. The entrepreneur asignes each project to a different manager. From the financing side nothing changes as the entrepreneur with $\omega$ units of inside equity issues $D=1-\omega$ units of debt on perfectly competitive markets returning a face value $r$ on date 2 (Note 5). The distribution of total returns from projects now is different from the model with a single project as the revenues come from the sum of two independent projects. Given total returns from projects, net of managerial bonus payments, Z, the expected profit of the entrepreneur can be expressed as: 


$$
\pi=E \max \{Z-r D, 0\}-\omega-\frac{M}{2} \sum_{i=1}^{2} m_{i}^{2}, \quad i=1,2 .
$$

where the first term represents the expected total returns from the 2 projects net of the return to debt-holders, the second term is the opportunity cost of entrepreneur's capital and the last term is the sum of monitoring costs. Similarly to the single project case, we characterize the symmetric equilibrium of the game with 2 projects (leaving the details in Appendix B).

In the case of two projects there are two contrasting effects: on one hand firm's revenues distribution is more concentrated around its mean, as a result of diversification, and this helps in curbing the moral hazard between debt-holders and shareholders (as shown in Cerasi \& Daltung, 2000); on the other hand the agency costs inside the firm increase due to convexity of monitoring costs as shareholders have to monitor two managers instead of one (Note 6).

Case B: Let us now consider the case where the size of the firm and the degree of diversification are correlated. This implies studying the case of an entrepreneur who invests 2 units of capital into 2 independent projects each one returning $R$ with probability $p, 0$ otherwise. The entrepreneur assignes each project to a different manager. From the financing side the entrepreneur with $\omega$ units of inside equity issues $D=2-\omega$ units of debt on perfectly competitive markets returning per unit a face value $r$ on date 2 . The expression of the expected profit of the entrepreneur is unchanged relatively to expression (12), however the distribution of total revenues from projects changes as the return in case of success is now doubled (it is enough to substitute $2 R$ instead of $R$ in all the expressions in Appendix B). Given that $D=1$, when investing into 2 projects the leverage of the firm decreases as debt is diluted on a larger base of assets. From the result in the previous section we know that the optimal managerial bonus decreases with leverage, therefore we expect the optimal bonus to be smaller in the case of 2 projects compared to case A.

Finally it is easy to show that in both cases A and B when $D=0$ the optimal managerial bonus is $b=0$, although equilibrium expected profit is lower in the case of 2 projects due to the convexity of monitoring costs.

\section{Empirical Implications}

The model has numerous empirical predictions on the level of managerial compensation. This paper shares with others (e.g., John \& John, 1993) the implication that managerial compensation and financial structure of the firm are to be studied together. This implication finds empirical support in Hartzell and Starcks (2003).

The model predicts that, once we control for the degree of diversification and leverage, firms paying higher managerial bonus to their managers have a lower cost of external debt. Evidence of a negative cross-sectional relation between managerial bonus and returns to bondholders is supportive of our model. Duru et al. (2005) find that larger managerial bonuses are associated with lower corporate bond yields and conclude that managerial bonuses help reduce the cost of external debt in contrast with the empirical evidence on the relation between managerial stock-holdings and bond yields (see, for instance, De Fusco et al., 1990, among others).

Another prediction of the model is that, once controls are set for firm size or degree of diversification, the higher the leverage, the greater the level of managerial bonus: as the acuteness of moral hazard increases, insiders shift the greater risk of default onto creditors due to limited liability. A greater managerial bonus serves to increase insiders' incentives. There is empirical evidence that more leveraged firms pay higher managerial bonuses to their managers. Again Duru et al. (2005) find that more leveraged firms tend to pay greater managerial bonuses to their managers. Other papers, such as Mehran (1992) and Berger et al. (1997), point out that managers in more leveraged firms have greater pay-performance sensitivity compensation. Evidence in support of the model is that managers in firms owned by a small number of shareholders -i.e., closely held firms -are rewarded with lower bonuses as shareholders' incentives to monitor are greater. Core et al. (1999) report that CEO pay-performance sensitivity is lower in firms with larger numbers of monitoring shareholders. Edwards et al. (2006) find that pay-performance sensitivity measured on managerial bonuses decreases when there are large independent shareholders. Furthermore, in management buyouts, that is in LBOs where the same management runs the company, greater leverage is accompanied by the adoption of greater pay-performance incentives for managers (see Kaplan, 1989).

Finally, a prediction of the model is that larger firms, when the increase in size is not accompanied by a greater leverage, should pay lower managerial bonuses. Although not a direct test of this prediction, Jensen and Murphy (1990) report empirical evidence that in larger firms the average sensitivity of managerial compensation to change in shareholders wealth is $1.85 \$$ compared with the figure of $8.05 \$$ in smaller firms. Further, Rose and Shepard (1997) show that changes in incumbent CEO compensation levels are negatively correlated with 
changes in the degree of corporate diversification.

\section{Conclusion}

We have analyzed, within a model, the optimal level of managerial bonus when firms are leveraged. When monitoring by shareholders is essential, although subject to moral hazard, managerial bonus provides a commitment to exert greater effort by insiders and this benefits external claim-holders. The model predicts that i) the cost of external debt may decrease the greater managerial pay-performance sensitivity, and that ii) the greater the leverage the larger the optimal pay-for-performance sensitivity. The analysis highlights how the way insiders are rewarded in a company affects the cost of external finance, once their compensation is disclosed to the financial markets.

The analysis faces several limitations due to the assumptions in the model. First of all, changing the seniority in the ordering of repayments may affect the results. The model assumes that managers are paid out of project revenues before bondholders, namely that they are senior compared to other creditors. In the case of a single project this assumption is neutral, while it is crucial for the results in the case of two projects. One possible effect of a different seniority in the ordering of repayment of managerial bonuses is that managers could be punished not only when shirking, but also when the firm is unable to repay bondholders (see for instance John and John, 1993; and Calcagno and Renneboog, 2007). The optimal priority of claims is out of the scope of this paper and requires further investigation.

Another limitation comes from the assumption, in the case of 2 projects, that each manager is assigned to a single risky project. Laux (2001) shows that assigning more than one project to each manager could be optimal, because it increases the set of states in which the entrepreneur can punish the manager. The interaction between internal hierarchy and managerial compensation is also left to future research.

In the analysis we have assumed away free-rider problems in monitoring between the different investors. De facto we are assuming that shareholders act as a single large shareholder who has maximum incentive to exert the monitoring effort; furthermore by assumption debt-holders do not monitor. When there are multiple monitoring claim-holders we have to take into account the reduced intensity of monitoring due to free-riding, as for instance in Carletti et al. (2007). This is again an interesting avenue for future research.

Finally, in this paper we have focused on managerial bonuses while ignoring other forms of pay-performance incentives, such as stock-options or direct stock-holdings to managers. Given our simple setup, where each manager is assigned to only one project and project returns are dichotomic, our bonus variable can be easily re-interpreted as managerial equity holdings. In a more general setup, we would have to distinguish between the different forms of managerial pay-performance compensation.

\section{Acknowledgements}

We thank Elena Carletti and Clara Graziano for their comments. We appreciated the excellent research assistance of Stefano Vezzoli. A previous draft has circulated under the title "Financial structure, managerial compensation and monitoring". The views expressed in this paper are solely the responsibility of the authors.

\section{References}

Aghion, P., \& Tirole, J. (1997). Real and Formal Authority in Organizations. Journal of Political Economy, 105(1), 1-29. https://doi.org/10.1086/262063

Berger, P., Ofek, E., \& Yermak, D. (1997). Managerial Entrenchment and Capital Structure Decisions. Journal of Finance, 52, 1411-1438. https://doi.org/10.1111/j.1540-6261.1997.tb01115.x

Berkovitz, E., Israel, R., \& Spiegel, Y. (2000). Managerial Compensation and Capital Structure. Journal of Economics \& Management Strategy, 9(4), 549-584. https://doi.org/10.1111/j.14309134.2000.00549.x

Burkart, M., Gromb, D., \& Panunzi, F. (1997). Large Shareholders, Monitoring and the Value of the Firm. Quarterly Journal of Economics, 112, 693-728. https://doi.org/10.1162/003355397555325

Calcagno, R., \& Renneboog, L. (2007). The incentive to give incentives: On the relative seniority of debt claims and managerial compensation. Journal of Banking and Finance, 31(6), 1795-1815. http://doi.org/10.1016/j.jbankfin.2006.09.006

Carletti, E., Cerasi, V., \& Daltung, S. (2007), Multiple-bank lending: Diversification and Free-riding in Monitoring. Journal of Financial Intermediation, 16, 425-451. http://doi.org/10.1016/j.jfi.2007.03.001

Cerasi, V., \& Daltung, S. (2000). The Optimal Size of a Bank: Costs and Benefits of Diversification. European Economic Review, 44(9), 1701-1726. http://doi.org/10.1016/S0014-2921(99)00008-2 
Core, J., Holthausen, R., \& Larcker, D. (1999). Corporate Governance, Chief Executive Officer Compensation, and Firm Performance. Journal of Financial Economics, 51, 371-406. http://doi.org/10.1016/S0304-405X(98)00058-0

De Fusco, R., Johnson, R., \& Zorn, T. (1990). The Effect of Executive Stock-Option Plans on Stockholders and Bondholders. Journal of Finance, 45, 617-628. http://doi.org/10.1111/j.1540-6261.1990.tb03707.x

Dessi, R. (2001). Implicit contracts, Managerial incentives, and Financial structure. Journal of Economics \& Management Strategy, 10(3), 359-390. http://doi.org/10.1111/j.1430-9134.2001.00359.x

Dewatripont, M., \& Tirole, J. (1994). A Theory of Debt and Equity: Diversity of Security and Manager-Shareholders Congruence. Quarterly Journal of Economics, 109, 1027-1054. https://doi.org/10.2307/2118355

Duru, A., Mansi, S., \& Reeb, D. (2005). Earnings-Based Bonus Plans and the Agency Costs of Debt. Journal of Accounting and Public Policy, 24, 431-447. http://doi.org/10.1016/j.jaccpubpol.2005.06.003

Edwards, J., Eggert, W., \& Welchenrieder, A. (2006). The Measurement of Firm Ownership and its Effect on Managerial Pay. CESIfo Working Paper No. 1774. Retrieved from https://ssrn.com/abstract=924734

Guembel, A., \& White, L. (2002). The Good and the Bad Cop: Complementarities between Debt and Equity in Disciplining Management. AFA 2003 Washington, DC Meetings. http://dx.doi.org/10.2139/ssrn.301842

Hartzell, J., \& Starcks, L. (2003). Institutional Investors and Executive Compensation. Journal of Finance, 58(6), 2351-2374. http://dx.doi.org/10.1046/j.1540-6261.2003.00608.x

Hellwig, M. (1998). Allowing for Risky Choices in Diamond's Model of Financial Intermediation as Delegated Monitoring. SFB Working Paper N. 98-04, University of Mannheim, Mannheim. Retrieved from http://ubmadoc.bib.uni-mannheim.de/13253/

Huddart, S. (1993). The Effect of a Large Shareholder on Corporate Value. Management Science, 39(11), 1407-1421. http://dx.doi.org/10.1287/mnsc.39.11.1407

Huson, M., Parrino, R., \& Starks, L. (2001). Internal Monitoring Mechanisms and CEO Turnover: A Long Term Perspective. Journal of Finance, 56(6), 2265-2297. http://dx.doi.org/10.1111/0022-1082.00405

Innes, R. D. (1990). Limited Liability and Incentive Contracting with Ex-ante Action Choices. Journal of Economic Theory, 52, 45-67. https://doi.org/10.1016/0022-0531(90)90066-S

Jensen, M. C., \& Meckling, W. (1976). Theory of the Firm: Managerial Behavior, Agency Costs and Ownership Structure. Journal of Financial Economics, 3, 305-360. https://doi.org/10.1016/0304-405X(76)90026-X

Jensen, M. C., \& Murphy, K. J. (1990). Performance Pay and Top-Management Incentives. Journal of Political Economy, 98(2), 225-264. https://doi.org/10.1086/261677

John, T., \& John, K. (1993). Top-Management Compensation and Capital Structure. Journal of Finance, 48(3), 949-974. https://doi.org/10.1111/j.1540-6261.1993.tb04026.x

Kaplan, S. (1989). The Effects of Management Buyouts on Operating Performance and Value. Journal of Financial Economics, 24(2), 217-254. https://doi.org/10.1016/0304-405X(89)90047-0

Laux, C. (2001). Limited-liability and Incentive Contracting with Multiple Projects. RAND Journal of Economics, 32(3), 514-526. Retrieved from http://www.jstor.org/stable/2696366

Mehran, H. (1992). Incentive Executive Plans, Corporate Control and Capital Structure. Journal of Financial and Quantitative Analysis, 27(4), 539-560. https://doi.org/10.2307/2331139

Murphy, K. J. (1999). Executive Compensation. In O. Ashenfelter, \& D. Card (Eds.), Handbook of Labor Economics (Vol. 3B, Chap. 38), Elsevier.

Rose, N., \& Shepard, A. (1997). Firm Diversification and CEO Compensation: Managerial Ability or Executive Entrenchment? RAND Journal of Economics, 28(3), 489-514. Retrieved from http://www.jstor.org.proxy.unimib.it/stable/2556026

Shapiro, C., \& Stiglitz, J. (1984). Equilibrium Unemployment as a Worker Discipline Device. American Economic Review, 74(3), 433-444. http://www.jstor.org/stable/1804018

\section{Notes}

Note 1. Note that assumption $\mathrm{E}>\mathrm{M}$ implies that the entrepreneur could be better off by firing the manager and 
running the project by himself. In the paper we show that, although the managerial effort is more costly than the entrepreneurial effort, inducing a positive managerial effort is optimal in order to reduce the cost of external finance.

Note 2. The decision to fire the manager is at the entrepreneur's discretion. This is in line with the empirical fact that managerial contracts are riskier when compared to workers' labor contracts. In particular there is no "good cause" clause in the managerial contract, while this is required in the worker's contract.

Note 3. This assumption guarantees that the entrepreneur will not fire the manager too often, given that the monitoring outcome is non-observable. After firing a manager, the entrepreneur hires another manager and pays him exactly the same bonus: thus he will not fire the old manager to save the bonus.

Note 4. In the real world projects can be selected from more or less correlated opportunities. This choice corresponds to compare for given leverage case A (non correlated projects) with the case in the previous section (perfect correlation among projects). See for instance Hellwig (1998) for a model where this choice is analyzed in a setting without delegation.

Note 5. While in the single project case debt and outside equity are equivalent financial contracts, this is not true anymore in the 2 projects case where debt dominates outside equity as incentive contract. We use the result in Innes (1990) who shows that debt is the optimal solution when the entrepreneur exerts a non-observable and costly effort.

Note 6. Following Laux (2001) one could show however that assigning 2 projects to the same manager and giving him a managerial contract where he is rewarded the bonus only if both projects succeed might reduce the agency costs.

\section{Appendix}

\section{A. Proofs}

Proof of Proposition 1: For a given debt rate $r$ and managerial effort e the entrepreneur chooses the monitoring intensity to maximize profit in (5), that is

$$
\frac{\partial \pi}{\partial m}=\Delta(\phi)(1-e)[R-b-r D]-M m=0,
$$

For a given debt rate $r$ and monitoring intensity $m$, the manager chooses the effort to maximize his utility in (4):

$$
\frac{\partial u}{\partial e}=\left(\Delta+m p_{L}\right) b-E e=0 .
$$

The Nash equilibrium is given by the couple of efforts $\{\widehat{m}, \widehat{e}\}$ solution to (13) and (14). In addition investors require their expected return to be equal to 1 as in (6). They rationally anticipate that the equilibrium effort is $\widehat{e}$ and monitoring $\widehat{m}$. Substituting equilibrium efforts in the investors' rationality condition in (6) gives (9).

Proof of Proposition 2: From equilibrium conditions in Proposition 1, substituting (9) into (8) gives

$$
\Delta(\phi)\left[R-\frac{D}{\widehat{p}(b)}\right]=M \frac{\widehat{m}(b)}{(1-\widehat{e}(b))}+b \Delta(\phi)
$$

where $\widehat{p}(b)$ is given by (10). When $b=0$ the above condition collapses to

$$
\Delta(\phi)\left[R-\frac{D}{\widehat{p}(0)}\right]=M \widehat{m}(0)
$$

with $\widehat{p}(0)=p_{L}+\widehat{m}(0) \Delta(\phi)$ since $\widehat{e}(0)=0$. We can compare $\widehat{p}(0)$ and $\widehat{p}(b)$ by using (15) and (16). It follows that $\widehat{p}(b)>\widehat{p}(0)$ if

$$
\frac{\widehat{m}(b)}{(1-\widehat{e}(b))}+\frac{b}{M} \Delta(\phi)>\widehat{m}(0) .
$$

It is useful to define the LHS of the above inequality, after substituting (7), as a generic function of $m \in[0,1]$

$$
g(m)=\frac{m}{1-\frac{b}{E}\left(\Delta+m p_{L}\right)}+\frac{b}{M} \Delta(\phi) .
$$


When $1-\frac{b}{E} \Delta>0, g^{\prime}(m)>0$ and $g^{\prime \prime}(m)>0$ for any $m$ with $g^{\prime}(0)>1$. For a small $b, b \leq \widehat{m}(0) \frac{M}{\Delta(\phi)}$, there must exists a $\bar{m} \in[0,1]$ such that $g(\bar{m})=\widehat{m}(0)$ : then $g(m)>\widehat{m}(0)$ for all $m>\bar{m}$ where $\bar{m} \equiv g^{-1}(\widehat{m}(0))$. This implies that $\widehat{p}(b)<\widehat{p}(0)$ if $\widehat{m}(b)<\bar{m}$ and $\widehat{p}(b)>\widehat{p}(0)$ if $\widehat{m}(b) \geq \bar{m}$. For a larger $b, \frac{E}{\Delta}>b>$ $\widehat{m}(0) \frac{M}{\Delta(\phi)}, g(m)>\widehat{m}(0)$ for all $m$, thus $\widehat{p}(b)>\widehat{p}(0)$ always.

Proof of Proposition 3: From the proof of Proposition 2, $\bar{m}$ is defined as $\bar{m}=g^{-1}(\widehat{m}(0))$. Since $g(m)$ is an increasing monotonic function, $\bar{m}$ behaves like this as well. It follows that $\bar{m}$ increases with $\widehat{m}(0)$. From equation (16) it can be easily seen that $\widehat{m}(0)$ decreases with $D$.

\section{B. Profits with 2 projects}

Total return on projects, net of managerial bonus payments, $Z$, has the Binomial distribution

$$
Z=\left\{\begin{array}{cc}
0 & \left(1-p_{i}\right)\left(1-p_{-i}\right) \\
\frac{R}{2}-b & p_{i}\left(1-p_{-i}\right)+p_{-i}\left(1-p_{i}\right) \\
R-2 b & p_{i} p_{-i}
\end{array}\right.
$$

and average equal to

$$
E(Z)=\left(p_{i}+p_{-i}\right)\left(\frac{R}{2}-b\right),
$$

where $p_{i}$ is given by (3), $i \in\{1,2\}$ and $i \neq-i$. Given the probability distribution of $Z$ expected profit in (12) can be rewritten as

$$
[R-2 b-r D] p_{i} p_{-i}+\max \left[\frac{R}{2}-b-r D, 0\right]\left[p_{i}\left(1-p_{-i}\right)+p_{-i}\left(1-p_{i}\right)\right]-\omega-\frac{M}{2} \sum_{i=1}^{2} m_{i}^{2}
$$

while debt-holders' expected return is constrained by the condition:

$$
r p_{i} p_{-i}+\frac{1}{D} \min \left\{r D, \frac{R}{2}-b\right\}\left[p_{i}\left(1-p_{-i}\right)+p_{-i}\left(1-p_{i}\right)\right]=1
$$

For a given debt rate $r$ and managerial effort $e_{i}$ the entrepreneur chooses the monitoring intensity to maximize expected profit in (18), that is

$$
\frac{\partial \pi}{\partial m_{i}}=\left\{[R-2 b-r D] p_{-i}+\max \left[\frac{R}{2}-b-r D, 0\right]\left(1-2 p_{-i}\right)\right\}\left(1-e_{i}\right) \Delta(\phi)-M m_{i}=0,
$$

for $i=1,2$ while, for a given debt rate $r$ and monitoring intensity $m_{i}$, each manager chooses the effort to maximize his utility in (4):

$$
\frac{\partial u_{i}}{\partial e_{i}}=\left(\Delta+m_{i} p_{L}\right) b-E e_{i}=0, \quad i=1,2 .
$$

The Nash equilibrium is given by the solution to (19),(20) and (21). In the symmetric Nash equilibrium $e_{i}=e_{-i}=\widehat{e}$ and $m_{i}=m_{-i}=\widehat{m}$. The system of equations that defines the symmetric equilibrium, collapses to the following system of equations

$$
\begin{aligned}
\left\{[R-2 b-\widehat{r} D] \widehat{p}+\max \left[\frac{R}{2}-b-\widehat{r} D, 0\right](1-2 \widehat{p})\right\}(1-\widehat{e}) \Delta(\phi)-M \widehat{m} & =0 \\
\left(\Delta+\widehat{m} p_{L}\right) b-E \widehat{e} & =0 \\
\widehat{r} \widehat{p}^{2}+\frac{1}{D} \min \left\{\widehat{r} D, \frac{R}{2}-b\right\} 2 \widehat{p}(1-\widehat{p}) & =1
\end{aligned}
$$

where $\widehat{p}$ is given by (10). We have to distinguish between two cases, depending on whether $\widehat{r}(b) D$ is above or below $\left(\frac{R}{2}-b\right)$.

Case (a): $\widehat{r}(b) D<\frac{R}{2}-b$. Equilibrium conditions (22) - (24), simplify to:

$$
\begin{aligned}
(1-\widehat{e}) \Delta(\phi)\left[\left(\frac{R}{2}-b\right)-\widehat{r} D(1-\widehat{p})\right]-M \widehat{m} & =0, \\
\widehat{r} \widehat{p}(2-\widehat{p}) & =1 .
\end{aligned}
$$


Substituting (26) into (25) we derive the single equation:

$$
(1-\widehat{e}) \Delta(\phi)\left[\left(\frac{R}{2}-b\right)-D\left(\frac{1-\widehat{p}}{\widehat{p}(1-\widehat{p})}\right)\right]-M \widehat{m}=0
$$

which defines the equilibrium together with (23).

Case (b): $\widehat{r}(b) D>\frac{R}{2}-b$. Equilibrium conditions (22) - (24), simplify to:

$$
\begin{aligned}
(1-\widehat{e}) \Delta(\phi)[R-2 b-\widehat{r} D] \widehat{p}-M \widehat{m} & =0 \\
\widehat{r} \widehat{p}^{2}+\frac{2}{D}\left(\frac{R}{2}-b\right) \widehat{p}(1-\widehat{p}) & =1 .
\end{aligned}
$$

Substituting (28) into (27) we derive the single equation:

$$
(1-\widehat{e}) \Delta(\phi)\left[R-2 b-\frac{D}{\widehat{p}}\right]-M \widehat{m}=0 .
$$

In both cases a) and b) the expected profit in the symmetric equilibrium can be derived from (18) and collapses to

$$
\widehat{\pi}(b)=2 \widehat{p}(b)\left(\frac{R}{2}-b\right)-1-M \widehat{m}(b)^{2} .
$$

\section{Copyrights}

Copyright for this article is retained by the author(s), with first publication rights granted to the journal.

This is an open-access article distributed under the terms and conditions of the Creative Commons Attribution license (http://creativecommons.org/licenses/by/4.0/). 